Article

\title{
Elderberry and Elderflower Extracts, Phenolic Compounds, and Metabolites and Their Effect on Complement, RAW 264.7 Macrophages and Dendritic Cells
}

\author{
Giang Thanh Thi Ho *, Helle Wangensteen and Hilde Barsett \\ School of Pharmacy, Department of Pharmaceutical Chemistry, University of Oslo, P.O. Box 1068, Blindern, \\ N-0316 Oslo, Norway; helle.wangensteen@farmasi.uio.no (H.W.); hilde.barsett@farmasi.uio.no (H.B.) \\ * Correspondence: g.t.t.ho@farmasi.uio.no; Tel.: +47-22-85-60-15
}

Academic Editors: Paula Andrade and Patrícia Valentão

Received: 31 January 2017; Accepted: 4 March 2017; Published: 8 March 2017

\begin{abstract}
Modulation of complement activity and inhibition of nitric oxide (NO) production by macrophages and dendritic cells may have therapeutic value in inflammatory diseases. Elderberry and elderflower extracts, constituents, and metabolites were investigated for their effects on the complement system, and on NO production in lipopolysaccharide (LPS)-activated RAW 264.7 macrophages and murine dendritic D2SC/I cells. The EtOH crude extracts from elderberry and elderflower and the isolated anthocyanins and procyanidins possessed strong complement fixating activity and strong inhibitory activity on NO production in RAW cells and dendritic cells. Phenolic compounds in the range of $0.1-100 \mu \mathrm{M}$ showed a dose-dependent inhibition of NO production, with quercetin, rutin, and kaempferol as the most potent ones. Among the metabolites, caffeic acid and 3,4-dihydroxyphenylacetic acid showed the strongest inhibitory effects on NO production in both cell lines, without having cytotoxic effect. Only 4-methylcatechol was cytotoxic at the highest tested concentration $(100 \mu \mathrm{M})$. Elderberry and elderflower constituents may possess inflammatory modulating activity, which increases their nutritional value.
\end{abstract}

Keywords: Sambucus nigra; elderberry; elderflower; complement system; nitric oxide; anti-inflammatory; metabolites; polyphenols; LPS; RAW 264.7 cells; dendritic D2SC/I cells

\section{Introduction}

Inflammation is one of the organism's attempts at self-protection, with the aim to remove harmful stimuli, including damaged cells, irritants, or pathogens. There is a growing research interest concerning anti-inflammatory natural products that will prevent and clarify the pathogenesis of various diseases such as cardiovascular diseases, diabetes, and chronic inflammatory diseases [1]. Numerous epidemiological studies indicate that an increase in the consumption of polyphenol-rich food is associated with a decrease in the incidence of cardiovascular diseases [1-4]. A large number of dietary polyphenols is consumed, and their anti-inflammatory activities have been reported [5]. This protective effect has been attributed in part to anti-inflammatory properties of polyphenols. At the level of bioactive compounds occurring in plants, substances such as polyphenols, polysaccharides, peptides, proteins, triterpenoids, lipid derivatives, and glycoproteins seem to modulate inflammatory as well as immunological processes [6,7].

The complement system plays an important role in the first-line defense against infections and holds important effector functions of the innate and the adaptive immune system. Complement participates in diseases with an immune component, such as autoimmune heart disease, multiple sclerosis, Alzheimer's disease, rheumatoid arthritis, and severe bacterial infections [8,9]. The inflammation 
process involves the activation of monocytes and/or macrophages. The activation of macrophages releases many inflammatory mediators such as interleukins (IL-1 $\beta$, IL-6), tumor necrosis factor (TNF)- $\alpha$, and inflammatory mediators including reactive oxygen species (ROS), nitric oxide (NO), and prostaglandin $\mathrm{E}_{2}\left(\mathrm{PGE}_{2}\right)$. NO formed by inducible $\mathrm{NO}$ synthase (iNOS) plays a vital role in host defense as it possesses cytotoxic effects on bacteria, virus, and tumor cells [10]. On the other hand, in high concentrations it can lead to tissue damage and inflammatory diseases such as rheumatoid arthritis, cardiovascular diseases, type 2 diabetes, chronic hepatitis, and pulmonary fibrosis [11]. For this reason, $\mathrm{NO}$ is a well-established marker of inflammation, and inhibition of its production might be a useful therapeutic strategy in inflammatory diseases [10].

Sambucus nigra L., also called black elder, is a deciduous tree that can grow up to $10 \mathrm{~m}$ high and has blue-black elderberries and cream-white elderflowers [12]. Both the elderberries and elderflowers have a long tradition in herbal medicine of being used to reduce inflammation and diabetic symptoms, as diuretics, and in the treatment of colds and flu. Studies have shown that elderberry and elderflower extracts possess diverse biological activities such as anti-inflammatory, antioxidant, and antidiabetes effects $[12,13]$. S. nigra has components with high biological activity, primarily flavonoids, such as flavonols, proanthocyanidins and anthocyanins, and simpler phenolic acids [12]. However, due to the complex bioavailability of polyphenols, it is difficult to know what the most relevant substance is after intake of elderberries and elderflowers in humans. Due to the fact that polyphenols are metabolized to simpler phenolic substances [14], it was also of interest to investigate whether these metabolites could contribute to an effect. In human intervention studies involving feeding elderberry extracts and anthocyanins, many potential metabolites have been identified in urine, serum, and feces [15,16], and selected metabolites were included in this study.

In the present study, we systematically investigated the effects of the elderberry and elderflower extracts, constituents, and metabolites on the complement fixating activity and on the NO production in lipopolysaccharide (LPS)-stimulated RAW 264.7 macrophages and murine dendritic D2SC/I cells.

\section{Results and Discussion}

\subsection{Extraction, Fractionation, and Chemical Characterization}

Freeze-dried elderberries and elderflowers were extracted with dichloromethane (DCM), $96 \% \mathrm{EtOH}, 50 \% \mathrm{EtOH}$, and water $\left(50\right.$ and $\left.100^{\circ} \mathrm{C}\right)$ on an accelerated solvent extraction instrument (ASE). The phenol-sulfuric acid test [17] and ${ }^{1} \mathrm{H}$ NMR analyses revealed that carbohydrates were present in the $50 \% \mathrm{EtOH}$ and 50 and $100{ }^{\circ} \mathrm{C}$ water extracts. ${ }^{1} \mathrm{H}$ and ${ }^{13} \mathrm{C}$ NMR analyses of the EtOH elderberry and elderflower extracts showed signals from aromatic compounds, organic acids, and carbohydrates. The $96 \%$ EtOH elderflower extract showed signals which could be attributed to rutin [18] and caffeoyl moieties [19], structures previously reported to be major constituents in the elderflowers [20]. From the acidic elderberry MeOH extract ( $800 \mathrm{~g}$ ), cyanidin-3-glucoside (340 mg, 0.043\% yield) and cyanidin-3-sambubioside ( $250 \mathrm{mg}, 0.031 \%$ yield), the major anthocyanins in elderberry, were isolated, in addition to the aglycone cyanidin $(270 \mathrm{mg}, 0.034 \%$ yield). The substances were identified by one- and two-dimensional NMR spectroscopy $\left({ }^{1} \mathrm{H},{ }^{13} \mathrm{C}, \mathrm{COSY}, \mathrm{APT}, \mathrm{HSQC}\right.$, and $\left.\mathrm{HMBC}\right)$ and the spectroscopic data were compared with those reported in the literature [21,22]. Chemical structures of the phenolic constituents and their metabolites from elderberries and elderflowers employed in this study are shown in Figures 1 and 2. 


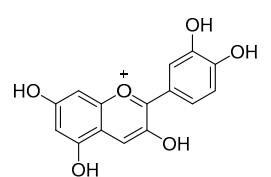

Cyanidin<smiles>Oc1cc(O)c2c(c1)O[C@H](c1ccc(O)c(O)c1)[C@H](O)C2c1c(O)cc(O)c2c1O[C@H](c1ccc(O)c(O)c1)[C@H](O)C2</smiles>

Procyanidin B2

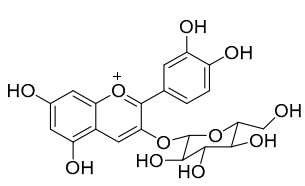

Cyanidin-3-glucoside

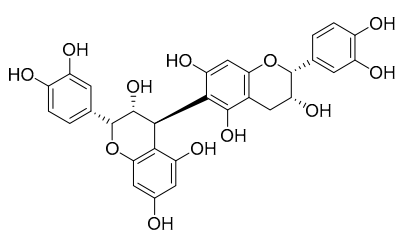

Procyanidin B5

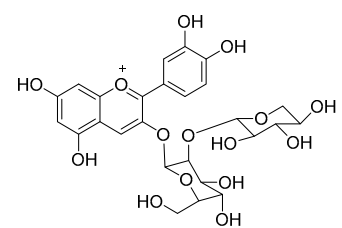

Cyanidin-3-sambubioside

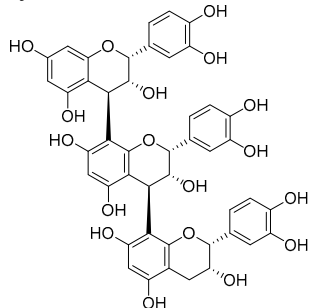

Procyanidin C1<smiles>[R]Cc1c([R])c([R])c([R])c([R])c1[R]</smiles>

\begin{tabular}{ccccccc}
\hline Chemical Compound & $\mathbf{R}_{\mathbf{1}}$ & $\mathbf{R}_{\mathbf{2}}$ & $\mathbf{R}_{\mathbf{3}}$ & $\mathbf{R}_{\mathbf{4}}$ & $\mathbf{R}_{\mathbf{5}}$ & $\mathbf{R}_{\mathbf{6}}$ \\
\hline p-Coumaric acid & $\mathrm{CH}=\mathrm{CH}-\mathrm{COOH}$ & $\mathrm{H}$ & $\mathrm{H}$ & $\mathrm{OH}$ & $\mathrm{H}$ & $\mathrm{H}$ \\
Homovanillic acid & $\mathrm{CH}_{2}-\mathrm{COOH}$ & $\mathrm{H}$ & $\mathrm{H}$ & $\mathrm{OH}$ & $\mathrm{OCH}_{3}$ & $\mathrm{H}$ \\
Phloroglucinol aldehyde & $\mathrm{CHO}$ & $\mathrm{OH}$ & $\mathrm{H}$ & $\mathrm{OH}$ & $\mathrm{H}$ & $\mathrm{OH}$ \\
4-Hydroxybenzoic acid & $\mathrm{COOH}$ & $\mathrm{H}$ & $\mathrm{H}$ & $\mathrm{OH}$ & $\mathrm{H}$ & $\mathrm{H}$ \\
Hippuric acid & $\mathrm{CO}-\mathrm{NH}-\mathrm{CH}_{2}-\mathrm{COOH}$ & $\mathrm{H}$ & $\mathrm{H}$ & $\mathrm{H}$ & $\mathrm{H}$ & $\mathrm{H}$ \\
Ferulic acid & $\mathrm{CH}=\mathrm{CH}-\mathrm{COOH}$ & $\mathrm{H}$ & $\mathrm{OCH}_{3}$ & $\mathrm{OH}$ & $\mathrm{H}$ & $\mathrm{H}$ \\
4-Hydroxybenzaldehyde & $\mathrm{CHO}$ & $\mathrm{H}$ & $\mathrm{H}$ & $\mathrm{OH}$ & $\mathrm{H}$ & $\mathrm{H}$ \\
Protocatechuic acid & $\mathrm{COOH}$ & $\mathrm{H}$ & $\mathrm{H}$ & $\mathrm{OH}$ & $\mathrm{OH}$ & $\mathrm{H}$ \\
Caffeic acid & $\mathrm{CH}=\mathrm{CH}-\mathrm{COOH}$ & $\mathrm{H}$ & $\mathrm{H}$ & $\mathrm{OH}$ & $\mathrm{OH}$ & $\mathrm{H}$ \\
Vanillic acid & $\mathrm{COOH}$ & $\mathrm{H}$ & $\mathrm{H}$ & $\mathrm{OH}$ & $\mathrm{OCH}_{3}$ & $\mathrm{H}$ \\
\hline
\end{tabular}

Figure 1. Structures of elderberry constituents and their metabolites.<smiles></smiles>

Structure A<smiles>O=C1CC(c2ccc(O)cc2)Oc2cc(O)cc(O)c21</smiles>

Structure B<smiles>[R3]C1Cc2c(O)cc(O)cc2O[C@H]1c1ccc(O)cc1</smiles>

Structure C

\begin{tabular}{cccc}
\hline Flavonoid & Structure & $\mathbf{R}_{3}$ & $\mathbf{R}_{3}{ }^{\prime}$ \\
\hline Quercetin & $\mathrm{A}$ & $\mathrm{OH}$ & $\mathrm{OH}$ \\
Quercetin-3-glucoside & $\mathrm{A}$ & O-Glucose & $\mathrm{OH}$ \\
Quercetin-3-rhamnoside & $\mathrm{A}$ & O-Rhamnose & $\mathrm{OH}$ \\
Rutin (quercetin-3-rutinoside) & $\mathrm{A}$ & O-Rutinose & $\mathrm{OH}$ \\
Kaempferol & $\mathrm{A}$ & $\mathrm{OH}$ & $\mathrm{H}$ \\
Kaempferol-3-rutinoside & $\mathrm{A}$ & O-Rutinose & $\mathrm{H}$ \\
Isorhamnetin & $\mathrm{A}$ & $\mathrm{OH}$ & $\mathrm{OCH}_{3}$ \\
Isorhamnetin-3-rutinoside & $\mathrm{A}$ & $\mathrm{O}-\mathrm{Rutinose}$ & $\mathrm{OCH}_{3}$ \\
Naringenin & $\mathrm{B}$ & - & - \\
Catechin & $\mathrm{C}$ & $\mathrm{OH}(\beta)$ & - \\
Epicatechin & $\mathrm{C}$ & $\mathrm{OH}(\alpha)$ & - \\
\hline & & &
\end{tabular}

Figure 2. Cont. 
<smiles>[R20]C1CC(O)(C(=O)O)CC([R20])C1O</smiles>

Chlorogenic acid $\left(\mathrm{R}_{1}=\right.$ Caffeoyl; $\left.\mathrm{R}_{2}=\mathrm{H}\right)$ Neochlorogenic acid $\left(\mathrm{R}_{1}=\mathrm{H} ; \mathrm{R}_{2}=\right.$ Caffeoyl $)$<smiles>O=C(O)/C=C/c1ccc(O)c(O)c1</smiles>

Caffeic acid<smiles>[R1]c1ccc([R1])c([R])c1[R]</smiles>

Structure D

\begin{tabular}{cccccc}
\hline Metabolites & Structure & $\mathbf{R}_{\mathbf{1}}$ & $\mathbf{R}_{\mathbf{2}}$ & $\mathbf{R}_{\mathbf{3}}$ & $\mathbf{R}_{4}$ \\
\hline Benzoic acid & $\mathrm{D}$ & $\mathrm{COOH}$ & $\mathrm{H}$ & $\mathrm{H}$ & $\mathrm{H}$ \\
3-Hydroxyphenylacetic acid & $\mathrm{D}$ & $\mathrm{CH}_{2}-\mathrm{COOH}$ & $\mathrm{H}$ & $\mathrm{OH}$ & $\mathrm{H}$ \\
3,4-Dihydroxyphenylacetic acid & $\mathrm{D}$ & $\mathrm{CH}_{2}-\mathrm{COOH}$ & $\mathrm{H}$ & $\mathrm{OH}$ & $\mathrm{OH}$ \\
4-Methylcatechol & $\mathrm{D}$ & $\mathrm{OH}$ & $\mathrm{OH}$ & $\mathrm{H}$ & $\mathrm{CH}_{3}$ \\
\hline
\end{tabular}

Figure 2. Structures of elderflower constituents and their metabolites.

\subsection{Complement Fixating Activity}

Due to the important role of the complement system in the immune system, complement modulation is involved in various diseases and considered as an interesting target for inflammatory diseases [23]. Elderberry and elderflower crude extracts, constituents, and metabolites were tested for complement fixating activity (Figure 3 ). The inhibitory concentration to give $50 \%$ effect $\left(\mathrm{IC}_{50}\right)$ values are presented in Table 1 for the crude extracts and in Table 2 for the constituents and metabolites. A pectic polysaccharide from Biophytum umbraculum Welw. (syn. B. petersianum Klotzsch) was used as positive control [24,25].

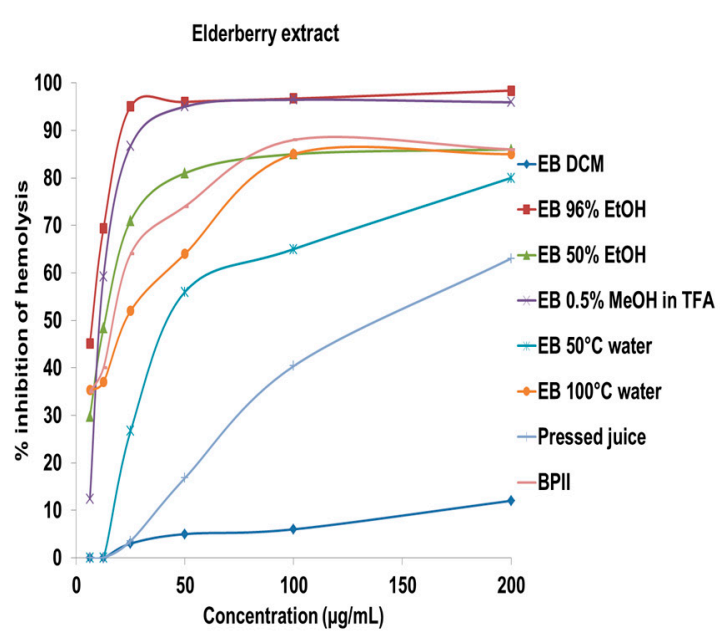

(A)

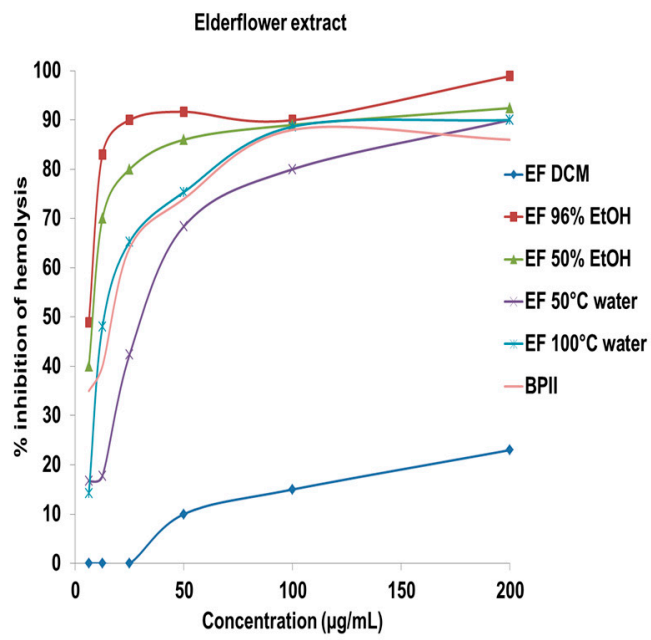

(B)

Figure 3. Cont. 


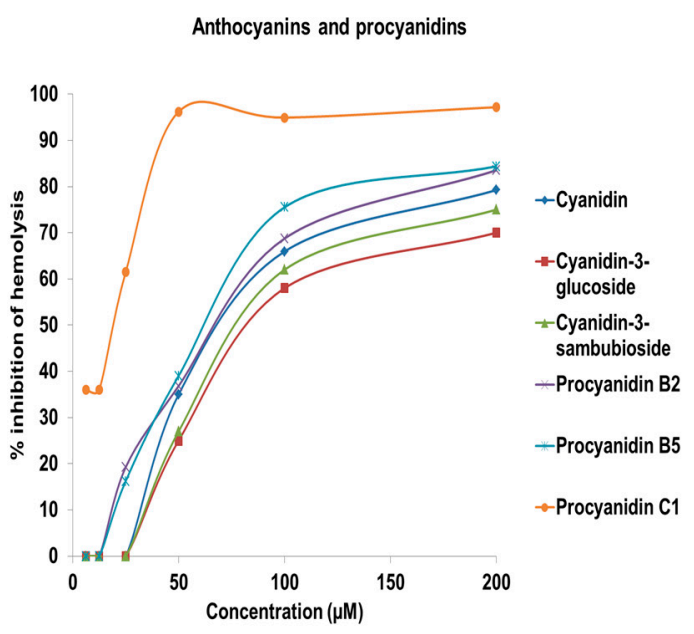

(C)

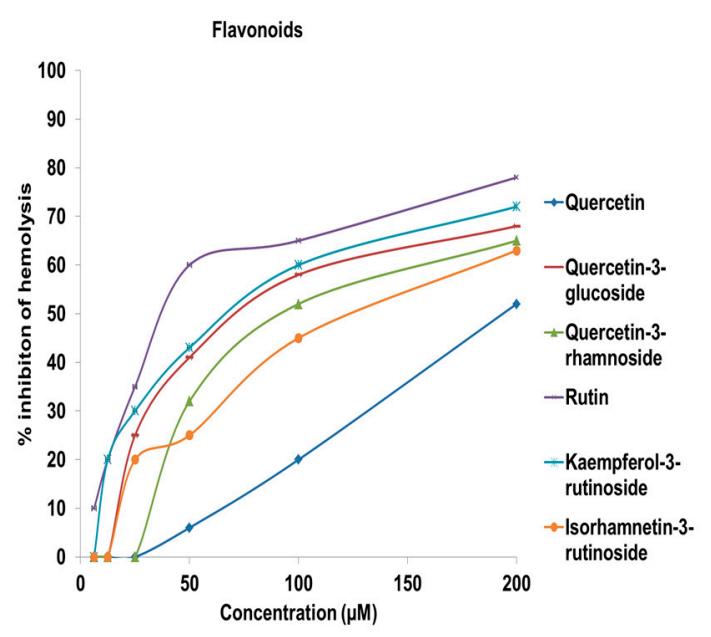

(D)

Figure 3. Complement fixating activity, expressed as \% inhibition of hemolysis of sensitized sheep erythrocytes. Inhibition of hemolysis by (A) crude extracts from elderberry; (B) crude extracts from elderflower; (C) isolated anthocyanins and procyanidins; and (D) flavonoids. The results represent the mean of three independent experiments.

Table 1. Complement fixating activity of crude extracts from elderberry (EB) and elderflower (EF). DCM, dichloromethane; TFA, trifluoroacetic acid.

\begin{tabular}{cc}
\hline Test Compounds & IC $_{\mathbf{5 0}}(\mu \mathrm{g} / \mathrm{mL})^{\mathbf{a}}$ \\
\hline Crude extracts from elderberry & \\
\hline EB DCM & $>200$ \\
EB 96\% EtOH & $7.8 \pm 2.3$ \\
EB 50\% EtOH & $13.4 \pm 2.9$ \\
EB 0.5\% TFA in MeOH & $12.3 \pm 1.9$ \\
EB 50 ${ }^{\circ} \mathrm{C}$ water & $44.9 \pm 5.3$ \\
EB $100{ }^{\circ} \mathrm{C}$ water & $23.3 \pm 3.5$ \\
Pressed juice & $142.4 \pm 13.1$ \\
\hline Crude extracts from elderflower & \\
\hline EF DCM & $>200$ \\
EF $96 \%$ EtOH & $6.5 \pm 1.5$ \\
EF 50\% EtOH & $8.9 \pm 2.2$ \\
EF $50{ }^{\circ} \mathrm{C}$ water & $32.3 \pm 5.2$ \\
EF $100{ }^{\circ} \mathrm{C}$ water & $14.4 \pm 3.1$ \\
BPII (positive control) & $17.7 \pm 1.5$ \\
\hline${ }^{a}$ IC $C$ Concentration to give $50 \%$ inhibition of
\end{tabular}

\footnotetext{
${ }^{\mathrm{a}} \mathrm{IC}_{50}$ : Concentration to give $50 \%$ inhibition of hemolysis.
}

Table 2. Complement fixating activity of flavonoids and metabolites from elderberries and elderflowers.

\begin{tabular}{cc}
\hline Test Compounds & IC $_{\mathbf{5 0}}(\boldsymbol{\mu M})^{\mathbf{a}}$ \\
\hline Flavonoids & \\
\hline Cyanidin & $74.2 \pm 3.4$ \\
Cyanidin-3-glucoside & $87.1 \pm 5.6$ \\
Cyanidin-3-sambubioside & $82.8 \pm 3.9$ \\
Procyanidin B2 & $70.6 \pm 4.5$ \\
\hline
\end{tabular}


Table 2. Cont.

\begin{tabular}{|c|c|}
\hline Test Compounds & $\mathrm{IC}_{50}(\mu \mathrm{M})^{\mathrm{a}}$ \\
\hline \multicolumn{2}{|l|}{ Flavonoids } \\
\hline Procyanidin B5 & $65.0 \pm 3.1$ \\
\hline Procyanidin $\mathrm{C} 1$ & $19.4 \pm 2.1$ \\
\hline Quercetin & $193.8 \pm 5.6$ \\
\hline Quercetin-3-glucoside & $76.5 \pm 2.6$ \\
\hline Quercetin-3-rhamnoside & $95.1 \pm 3.1$ \\
\hline Rutin & $40.0 \pm 2.6$ \\
\hline Kaempferol & $>200$ \\
\hline Kaempferol-3-rutinoside & $70.6 \pm 3.8$ \\
\hline Isorhamnetin & $>200$ \\
\hline Isorhamnetin-3-rutinoside & $127.8 \pm 4.8$ \\
\hline Naringenin & $>200$ \\
\hline Catechin & $>200$ \\
\hline Epicatechin & $>200$ \\
\hline \multicolumn{2}{|l|}{ Metabolites } \\
\hline$p$-Coumaric acid & $>200$ \\
\hline Homovanillic acid & $>200$ \\
\hline Phloroglucinol aldehyde & $>200$ \\
\hline 4-Hydroxybenzoic acid & $>200$ \\
\hline Hippuric acid & $>200$ \\
\hline Ferulic acid & $>200$ \\
\hline 4-Hydroxybenzaldehyde & $>200$ \\
\hline Protocatechuic acid & $>200$ \\
\hline Caffeic acid & $>200$ \\
\hline Vanillic acid & $>200$ \\
\hline Benzoic acid & $>200$ \\
\hline 3-Hydroxybenzoic acid & $>200$ \\
\hline 3,4-Dihydroxyphenylacetic acid & $>200$ \\
\hline 4-Methylcatechol & $>200$ \\
\hline
\end{tabular}

${ }^{\mathrm{a}} \mathrm{IC}_{50}$ : Concentration to give $50 \%$ inhibition of hemolysis.

Among the elderberry crude extracts, the acidic $\mathrm{MeOH}\left(\mathrm{IC}_{50} 12.3 \pm 1.9 \mu \mathrm{g} / \mathrm{mL}\right)$, the $96 \% \mathrm{EtOH}$ $\left(\mathrm{IC}_{50} 7.8 \pm 2.3 \mu \mathrm{g} / \mathrm{mL}\right)$, and the $50 \% \mathrm{EtOH}\left(\mathrm{IC}_{50} 13.4 \pm 2.9 \mu \mathrm{g} / \mathrm{mL}\right)$ extracts showed the highest complement fixating activity. Thus, the acidic $\mathrm{MeOH}$ extract and the $\mathrm{EtOH}$ extracts have the highest selectivity for both polyphenols and components with high complement fixating activity. The $50{ }^{\circ} \mathrm{C}$ water and $100{ }^{\circ} \mathrm{C}$ water extracts containing polysaccharides also possessed complement fixating activities, in accordance with a previous report [26]. The $\mathrm{IC}_{50}$ values of cyanidin-3-glucoside and cyanidin-3-sambubioside, on a weight basis, are $18.0 \mu \mathrm{g} / \mathrm{mL}$ and $13.4 \mu \mathrm{g} / \mathrm{mL}$, which is higher compared to the acidic elderberry $\mathrm{MeOH}$ extract $\left(\mathrm{IC}_{50} 12.3 \mu \mathrm{g} / \mathrm{mL}\right.$ ). There might be other strong complement fixating compounds in the acidic extract, or the effect is caused by synergism. The aglycone cyanidin showed somewhat higher activity compared to cyanidin-3-glucoside and cyanidin-3-sambubioside. The anthocyanins seem to have a lower inhibition of hemolysis compared to the corresponding aglycone. Proanthocyanidins that are present in small amounts in elderberries also possessed strong inhibitory activity on the hemolysis. Trimeric procyanidin $\mathrm{C} 1\left(\mathrm{IC}_{50} 19.4 \pm 2.1 \mu \mathrm{M}\right)$ possessed stronger complement fixating activity compared to the dimeric procyanidins $\mathrm{B} 2\left(\mathrm{IC}_{50} 70.6 \pm 4.5 \mu \mathrm{M}\right)$ and B5 $\left(\mathrm{IC}_{50} 65.0 \pm 3.1 \mu \mathrm{M}\right)$, while the monomers epicatechin and catechin were almost inactive $(>200 \mu \mathrm{M})$. These results are in agreement with those reported previously $[27,28]$. Due to the fact that anthocyanins are metabolized to simpler phenolic substances, it was also of interest to investigate whether these metabolites that are detected in urine, feces and plasma after consumption of elderberries could have complement fixating activity. However, the metabolites shown in Figure 1 did not show any particular complement fixating activity from 0.1 to $200 \mu \mathrm{M}$. 
The $96 \%$ EtOH and 50\% EtOH elderflower extracts were the most potent inhibitors of hemolysis in the complement assay, followed by the water extracts. Pectic polysaccharides present in the water extracts might be a reason for the high complement fixating activity observed, in accordance with previous results [26,29,30]. Rutin ( $\left.\mathrm{IC}_{50} 40.0 \pm 2.6 \mu \mathrm{M}\right)$, quercetin-3-rhamnoside $\left(\mathrm{IC}_{50} 95.1 \pm 3.1 \mu \mathrm{M}\right)$, and quercetin-3-glucoside $\left(\mathrm{IC}_{50} 76.5 \pm 2.6 \mu \mathrm{M}\right)$ showed a higher complement fixating activity compared to the aglycone quercetin $\left(\mathrm{IC}_{50} 193.8 \pm 5.6 \mu \mathrm{M}\right)$, which is also reported previously [27,31]. Quercetin has even been reported to be inactive in a study [32]. The same trend is observed for kaempferol-3-rutinoside $\left(\mathrm{IC}_{50} 70.6 \pm 3.8 \mu \mathrm{M}\right)$ and its aglycone kaempferol $(>200 \mu \mathrm{M})$ and for isorhamnetin-3-rutinoside $\left(\mathrm{IC}_{50} 127.8 \pm 4.8 \mu \mathrm{M}\right)$ and its aglycone isorhamnetin $\left(\mathrm{IC}_{50}>200 \mu \mathrm{M}\right)$. An earlier study showed that kaempferol and quercetin-3-rhamnoside had weak complement fixating activity with $\mathrm{IC}_{50}$ values 730 and $440 \mu \mathrm{M}$, respectively [32,33]. It appeared that the flavonol glycosides were more active than their aglycones in this system. These results are opposite to the activity of anthocyanins versus their aglycone. The presence of sugars seems to be important for complement fixating activity of the flavonoids included in this study. The metabolites from the elderflower phenolics (Figure 2) showed no particular complement fixating activity at the highest concentration tested $\left(\mathrm{IC}_{50}>200 \mu \mathrm{M}\right)$.

\subsection{Inhibition of NO Production in LPS-Stimulated RAW 264.7 Macrophages and Dendritic D2SC/I Cells, and Cell Viability}

During inflammation, bacterial products and proinflammatory cytokines induce the formation of large amounts of nitric oxide (NO) by inducible nitric oxide synthase (iNOS), and compounds that inhibit NO production can be inflammatory modulators. Exposure of lipopolysaccharides (LPS) to macrophages triggers several disadvantageous cellular responses and causes responses similar to inflammation, sepsis, and stroke. Macrophages and dendritic cells play a major role in the initiation and modulation of immune responses [34]. An induction of iNOS in dendritic cells or macrophages via stimulation with LPS has been described in the literature [35]. The dendritic cells may function as the most potent antigen-presenting cells for $\mathrm{T}$ cell activation, and increased levels of $\mathrm{NO}$ may inhibit $\mathrm{T}$ cell proliferation and apoptosis in the dendritic cells [34]. The proposed mechanism associated with the inhibition of NO production in macrophages is scavenging of NO radicals, direct inhibition of iNOS enzyme activity, and/or inhibition of iNOS gene expression [11]. The inhibitory effect of elderberry and elderflower extracts, constituents, and metabolites on NO production in RAW 264.7 cells and dendritic D2SC/I cells exposed to LPS are shown in Figure 4. The NO concentration after exposure to the LPS control was $10.3 \pm 2.1 \mu \mathrm{M}$ for the RAW 264.7 cells and $14.6 \pm 2.4 \mu \mathrm{M}$ for the dendritic D2SC/I cells. Quercetin, which is a constituent in elderflower, was used as a positive control as well [11].

Among the crude extracts, the $96 \%$ EtOH elderflower extract $(100 \mu \mathrm{g} / \mathrm{mL})$ showed the highest NO inhibition in RAW 264.7 and dendritic cells $(75.6 \% \pm 3.1 \%$ and $80.3 \% \pm 2.9 \%$, respectively) followed by the $96 \%$ EtOH elderberry extract $(57.3 \% \pm 5.1 \%$ and $47.8 \% \pm 8.7 \%$, respectively) (Figure $4 \mathrm{~A}, \mathrm{~B})$. A high content of phenolic compounds, revealed by ${ }^{1} \mathrm{H}$ NMR spectroscopy, in the $96 \%$ EtOH elderberry and elderflower extracts could be the reason for the high NO inhibitory activity. The DCM elderberry and elderflower extracts exhibited little effect on NO production in LPS-activated RAW 264.7 and dendritic D2SC/I cells. The water extracts induced the production of NO, explained by the presence of pectic polysaccharides, which previously have shown macrophage stimulation $[26,29,30]$. The elderberry and elderflower crude extracts did not show any cytotoxic effects against RAW 264.7 macrophages and dendritic D2SC/I cells at $100 \mu \mathrm{g} / \mathrm{mL}(81.2 \%-105.6 \%$ cell viability). Also, cold-pressed raw juice possessed moderate NO inhibition on LPS-activated RAW 264.7 and dendritic cells. 
A

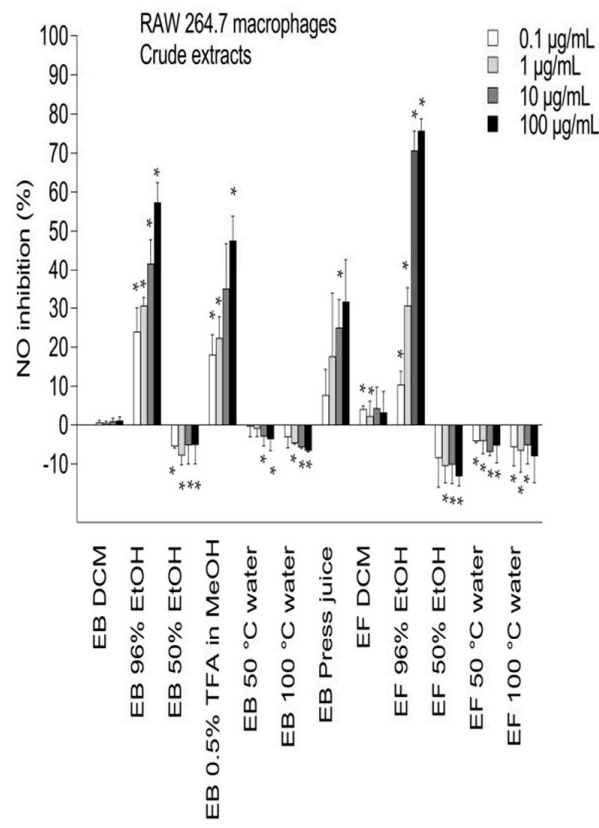

C

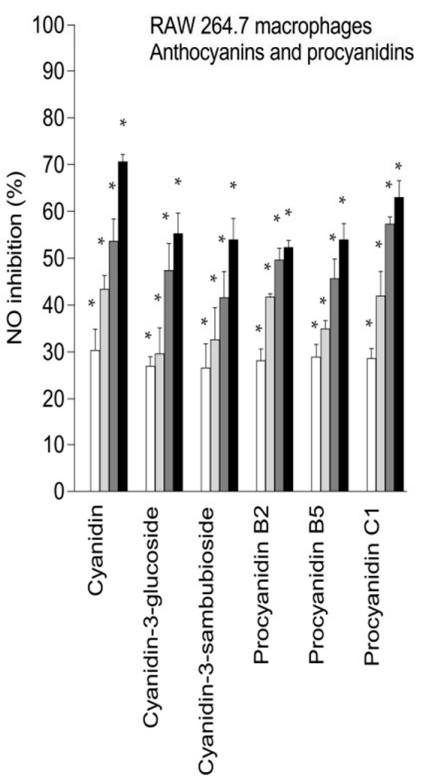

B

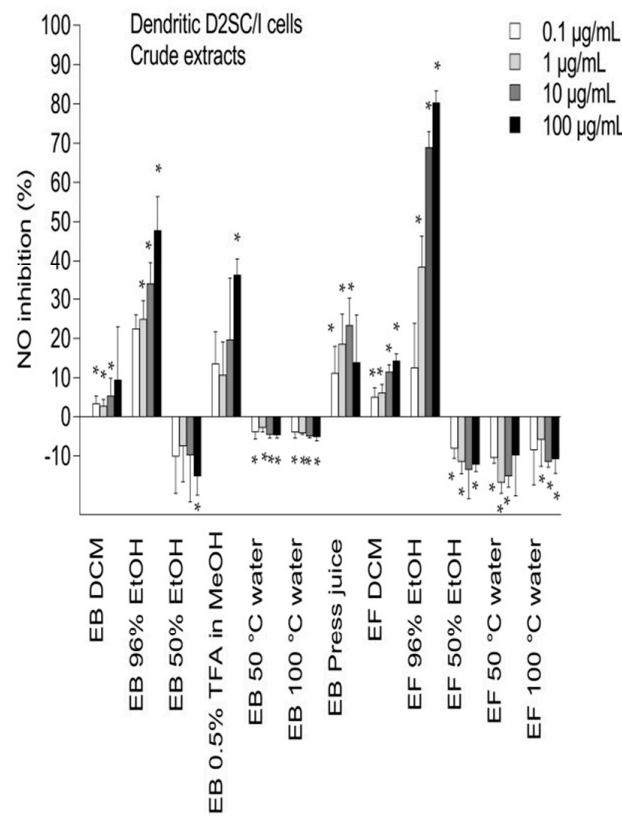

D

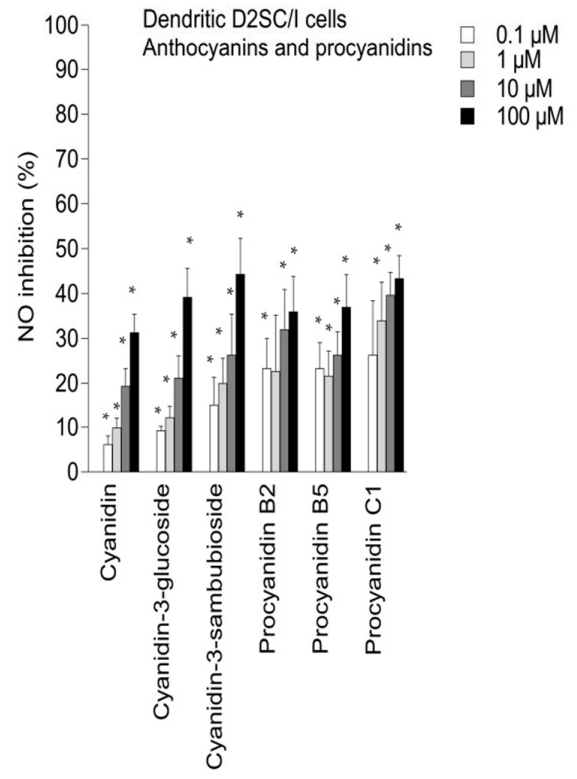

Figure 4. Cont. 

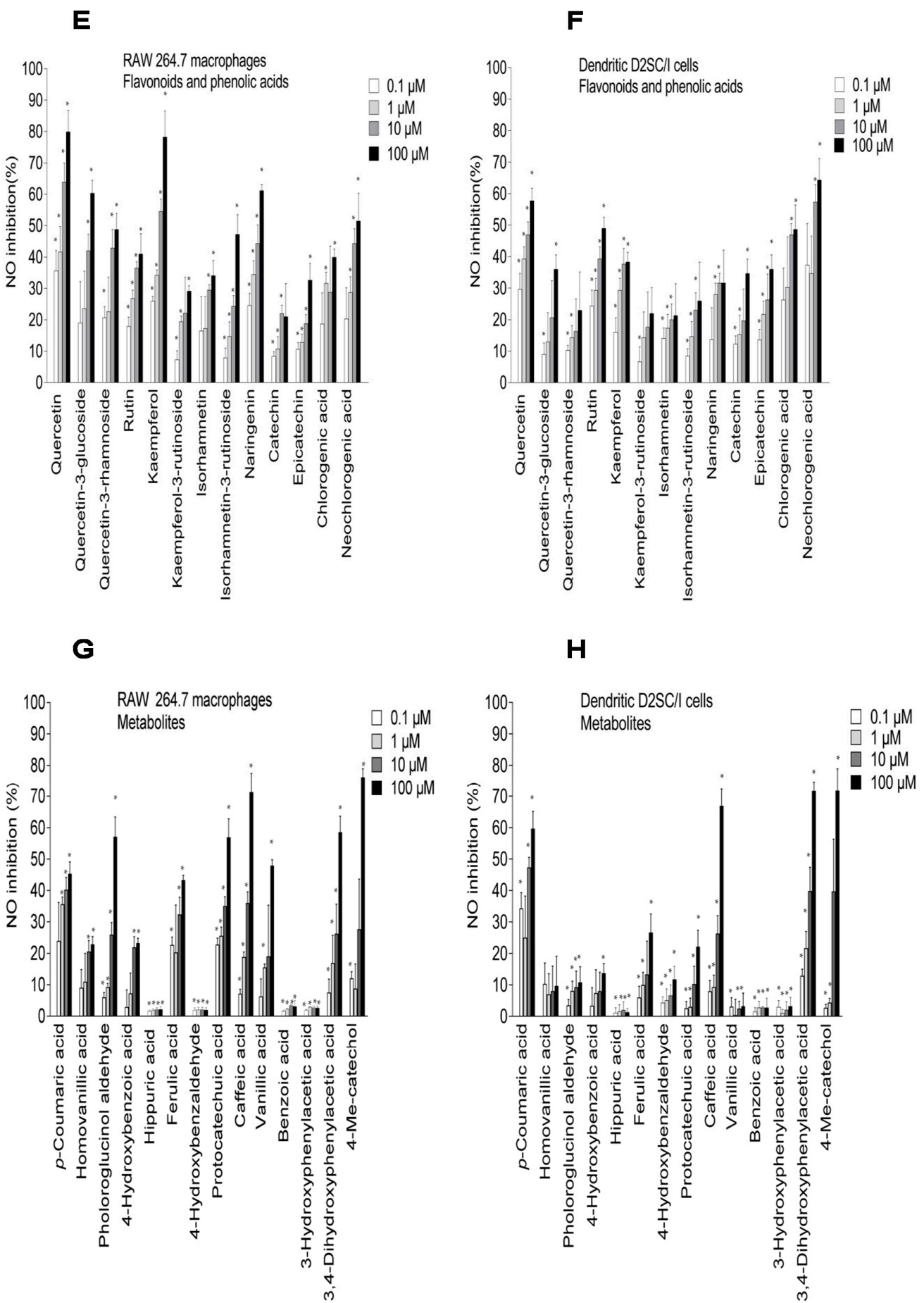

Figure 4. Inhibitory effects of elderberry (EB) and elderflower (EF) crude extracts (A,B); anthocyanins and proanthocyanidins $(\mathbf{C}, \mathbf{D})$; flavonoids and phenolic acids $(\mathbf{E}, \mathbf{F})$; and metabolites $(\mathbf{G}, \mathbf{H})$ on NO production in lipopolysaccharide (LPS)-activated RAW 264.7 macrophages (A,C,E,G) and dendritic D2SC/I cells $(\mathbf{B}, \mathbf{D}, \mathbf{F}, \mathbf{H})$. The experiments were repeated independently three times, and results shown are expressed as the average \pm SEM. ${ }^{*} p<0.05$ as compared to response of lipopolysaccharide (LPS) (0.1\% DMSO) alone.

The elderberry anthocyanins and procyanidins showed high inhibitory effects on NO production (Figure 4C,D) and no toxicity towards the RAW 264.7 and dendritic D2SC/I cells (Figure 5C,D). The aglycone cyanidin showed a stronger inhibitory effect when compared to cyanidin-3-glucoside 
and cyanidin-3-sambubioside in the RAW 264.7 cells, and the effect shown was dose-dependent (Figure 4C). Cyanidin-3-glucoside and cyanidin-3-sambubioside, however, showed a higher inhibitory effect on NO production compared to its aglycone cyanidin in the dendritic cells at $100 \mu \mathrm{M}$ (Figure 4D). The sugar moiety attached to cyanidin aglycone seems in any case to influence the NO inhibitory effect in both the RAW 264.7 cells and the dendritic D2SC/I cells. Cyanidin glycosides are present in high amounts in elderberries and may therefore be the most important contributor to the NO inhibition in the RAW 264.7 cells and the dendritic D2SC/I cells. The trimeric procyanidin C1 showed somewhat higher inhibitory activity compared to the dimers procyanidin B2 and procyanidin B5.

Quercetin-3-glucoside, quercetin-3-rhamnoside, and rutin (quercetin-3-rutinoside) showed NO inhibition of $60.4 \% \pm 4.0 \%, 48.8 \% \pm 5.1 \%$, and $40.9 \% \pm 6.5 \%$ at $100 \mu \mathrm{M}$ in RAW 264.7 cells, respectively (Figure 4E), while the aglycone quercetin had a NO inhibition of $79.9 \% \pm 6.9 \%$ at $100 \mu \mathrm{M}$. Glycosylated forms seemed to have a weaker NO inhibition in the RAW 264.cells. The same trend was also found for kaempferol and kaempferol-3-rutinoside. Glycosylation of the flavonoids might lead to increased hydrophilicity and steric hindrance, which again results in reduced absorption or penetration into the cells. This might influence the NO inhibitory effect in the RAW 264.7 cells. Similar results have also been reported previously [2,11]. NO inhibition by flavonoids in dendritic D2SC/I cells (Figure 4F) showed almost the same pattern as in RAW 264.7 cells, but generally the activity in dendritic cells was somewhat lower. Kaempferol showed a strong NO inhibition in the RAW 264.7 cells and weaker inhibition in the dendritic cells. Rutin (glycosylated with a disaccharide), however, was a more potent NO inhibitor in the dendritic cells than in the macrophages, and was also more active than the other quercetin-glycosides tested. Dendritic cells have many of the same properties as macrophages, but their surface phenotype and functional characteristics indicate that they belong to a unique lineage. The polyphenols might act on different cellular targets in the RAW 264.7 cells and dendritic cells. Epicatechin and catechin showed a small but significant inhibitory effect compared to the LPS control in both the RAW 264.7 cells, and showed similar inhibitory effect in dendritic D2SC/I cells. Chlorogenic acid has previously been reported to have no inhibitory effect in RAW 264.7 cells and in J774 macrophages [2,11]. In our study, chlorogenic acid showed NO inhibitory activity in the RAW 264.7 and dendritic D2SC/I cells, with the highest activity in dendritic cells. At the highest concentration tested $(100 \mu \mathrm{M})$, neochlorogenic acid inhibited NO production with $64.3 \% \pm 6.8 \%$ in the dendritic D2SC/I cells, and had somewhat lower activity $51.5 \% \pm 8.8 \%$ in RAW cells. Both rutin and chlorogenic acid are present in high amounts in elderflower [20] and may therefore be the most important contributors to modulation of inflammatory effects.

The polyphenols are absorbed rather poorly from the gut and are extensively metabolized in vivo, suggesting that the accumulation of multiple phenolic metabolites may be responsible for some of the reported bioactivity of the polyphenols. The metabolites showed somewhat similar effects of NO inhibition in macrophages and dendritic cells. However, there were some variations in activity from one compound to the other. Phloroglucinol aldehyde, protocatechuic acid, and vanillic acid showed a considerably higher inhibitory effect on NO production in the RAW 264.7 cells compared to the dendritic cells. Caffeic acid, 3,4-dihydroxyphenylacetic acid, protocatechuic acid, and phloroglucinol aldehyde were the most active metabolites, which inhibited the NO production in LPS-activated RAW 264.7 cells by $71.3 \% \pm 6.2 \%, 58.5 \% \pm 5.1 \%, 57.1 \% \pm 6.2 \%$, and $56.9 \% \pm 5.8 \%$, respectively, at $100 \mu \mathrm{M}$. Protocatechuic acid, the major metabolite from cyanidin-3-glucoside, showed the same inhibitory effect on NO production compared to cyanidin 3-glucoside in RAW 264.7 cells at $100 \mu \mathrm{M}$ $(56.9 \% \pm 5.9 \%$ and $55.3 \% \pm 4.0 \%$, respectively). Previous studies have reported that protocatechuic acid and caffeic acid have strong anti-inflammatory properties [36,37]. In LPS-activated dendritic D2SC/I cells, 3,4-dihydroxyphenylacetic acid, caffeic acid, and $p$-coumaric acid were the most potent metabolites that inhibited NO production by $>50 \%$ at $100 \mu \mathrm{M}$ without showing cytotoxicity. 4-Methylcatechol was toxic at $100 \mu \mathrm{M}$ against RAW 264.7 cells and dendritic D2SC/I cells $(45.3 \% \pm 3.6 \%$ and $51.2 \% \pm 8.1 \%$ cell viability, respectively) and the strong NO inhibition observed for 4-methylcatechol at $100 \mu \mathrm{M}$ could be caused by cell cytotoxicity (Figure 5G,H). 

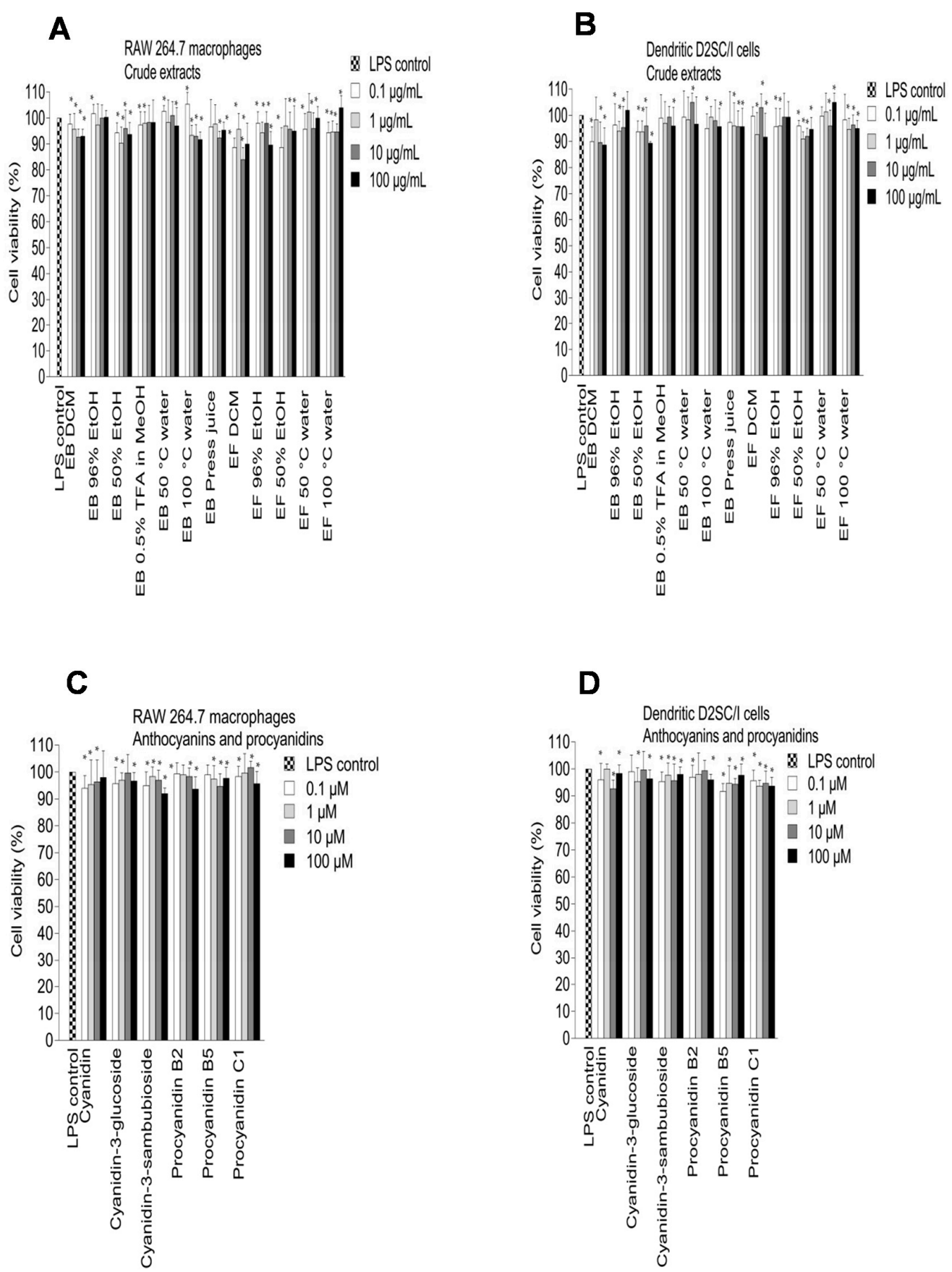

Figure 5. Cont. 

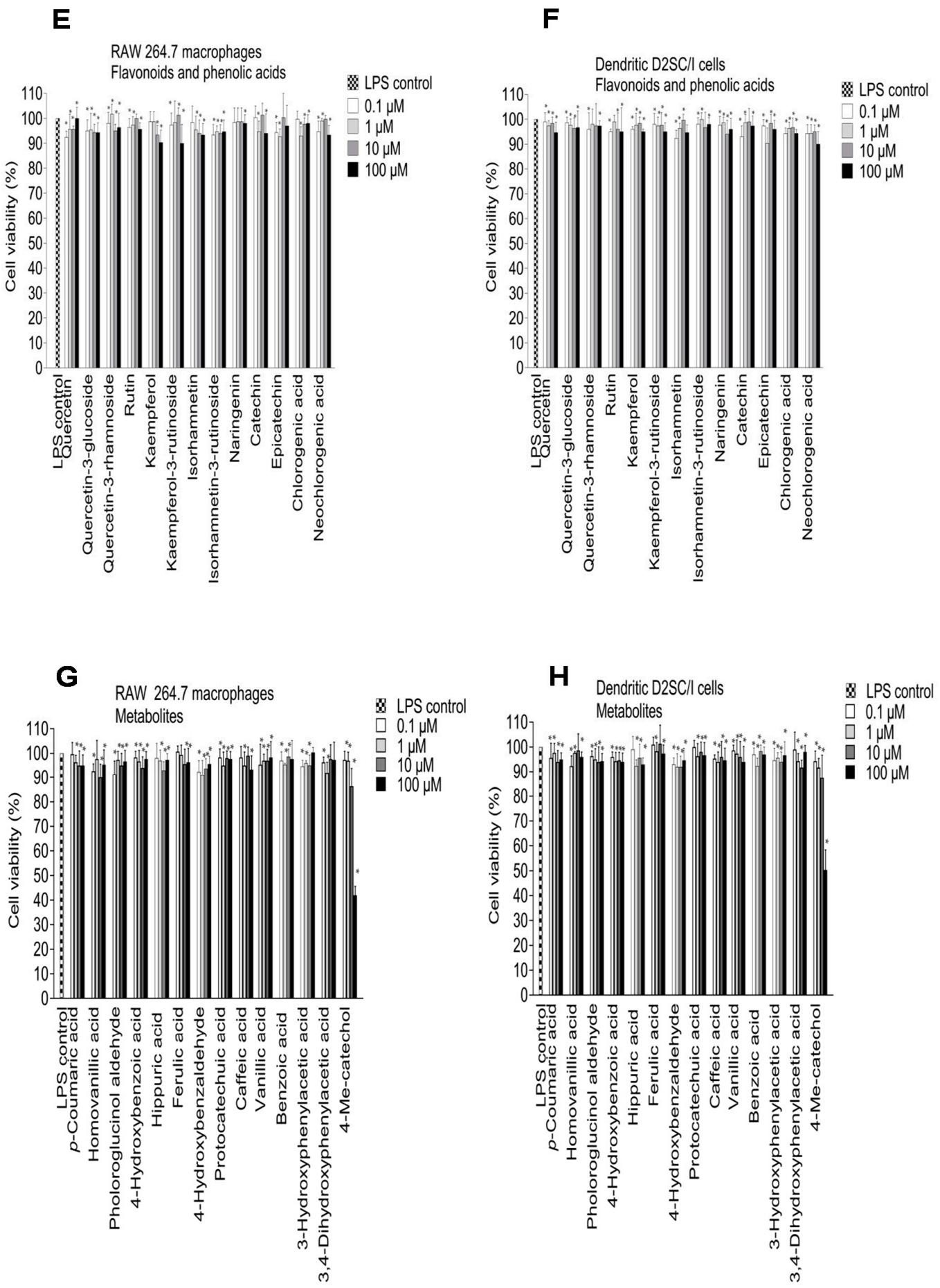

Figure 5. Effect of elderberry (EB) and elderflower (EF) crude extracts (A,B); anthocyanins and proanthocyanidins $(\mathbf{C}, \mathbf{D})$; flavonoids and phenolic acids $(\mathbf{E}, \mathbf{F})$ on cell viability in LPS-activated RAW 264.7 cells (A,C,E,G) and dendritic D2SC/I cells (B,D,F,H). Cell viability was assessed using the MTT assay. The experiments were repeated independently three times, and results shown are expressed as the average \pm SEM. ${ }^{*} p<0.05$ vs. LPS $(0.1 \%$ DMSO) as control.

The bioavailability of elderberry anthocyanins is reported to be low; less than $0.1 \%$ of the ingested dose has been detected in humans [38]. Concentrations of $0.1-0.4 \mu \mathrm{M}$ have been detected for the elderberry anthocyanins in blood and urine after intake of elderberry extract (500-700 mg anthocyanins) $[15,16]$. The bioavailability of the anthocyanin metabolites was reported to be $60-$ 
and 45-fold higher than their parent compounds based on concentrations in urine and plasma, respectively $[15,16]$. Bioavailability studies in humans of elderflower and their phenolic compounds are still missing. However, Williamson and Manach [39] reported that polyphenol concentrations of less than $10 \mu \mathrm{M}$ may have physiological effects. This indicates that concentrations used in this study might have a clinical relevance.

As far as we know, this is the first study comparing the inhibitory effects on NO production in LPS-activated RAW 264.7 cells and dendritic D2SC/I cells of elderberry and elderflower extracts. In addition, this study gives a comprehensive overview of complement fixating activity and NO inhibition in RAW 264.7 and dendritic cells of the major phenolic compounds present in elderberry and elderflower. Moreover, for the first time we showed that the metabolites in physiological concentrations inhibited the NO production in macrophages and dendritic cells. In sum, these results bring new and supportive data to the inflammatory modulating properties of the phenolic compounds present in elderberries and elderflowers. Thus, intake of elderberry and elderflower might help to regulate inflammatory diseases.

\section{Materials and Methods}

\subsection{Plant Material}

Fresh elderberries (cultivar "Sampo") and raw elderberry juice (made by cold-pressing followed by filtering to remove peels and seeds and heating to $68^{\circ} \mathrm{C}$ ) were gifts from cultivator Rune Hatleli, Fresvik in Sogn, Norway. The berries were harvested in October 2014 and stored at $-20{ }^{\circ} \mathrm{C}$ until extraction. Certified ecologically cultivated flowers of Sambucus nigra L., harvested in Norway October 2012, were purchased from Odins Marked, Oslo, Norway (org. No: 876905892) in November 2012. Voucher specimens of elderberries (No. EB1010) and elderflowers (No. EF1020) are deposited in the Pharmacognosy section, School of Pharmacy, University of Oslo, Norway.

\subsection{Chemicals}

4-Hydroxybenzaldehyde, 4-hydroxybenzoic acid, caffeic acid, homovanillic acid, vanillic acid, protocatechuic acid, phloroglucinol aldehyde, hippuric acid, ferulic acid, $p$-coumaric acid, quercetin, chlorogenic acid, neochlorogenic acid, epicatechin, catechin, kaempferol, kaempferol-3-rutinoside, 3-hydroxyphenylacetic acid, 3,4-dihydroxyphenylacetic acid, isorhamnetin-3-rutinoside, naringenin, isorhamnetin, rutin, quercetin, quercetin-3-rhamnoside, quercetin-3-glucoside, 4-methylcatechol, benzoic acid, DMSO- $d_{6}, \mathrm{CD}_{3} \mathrm{OD}$, Griess reagent $\mathrm{A}$, Griess reagent B, cell proliferation kit I (MTT), and bovine serum albumin (BSA) were purchased from Sigma-Aldrich (St. Louis, MO, USA). Proanthocyanidins B2, B5, and C1 were obtained from Plantchem (Klepp, Norway). Dulbecco's modified Eagle's medium (DMEM-Glutamax ${ }^{\mathrm{TM}}, 5.5 \mathrm{mM}$ ), fetal bovine serum, and penicillin-streptomycin-amphotericin B were obtained from Gibco Life Technologies (Paisley, UK). Corning CellBIND tissue culture plates were obtained from Corning Life-Sciences (Schiphol-Rijk, The Netherlands). All other reagents were of the highest purity available.

\subsection{Extraction and Isolation of Anthocyanins}

Elderberries and elderflowers were extracted according to Ho et al. [40]. For extraction, $30 \mathrm{~g}$ freeze-dried berries or flowers were mixed with diatomaceous earth (Dionex, Sunnyvale, CA, USA) (4:1) and loaded in a $100 \mathrm{~mL}$ steel cartridge. The elderberries and elderflowers were then extracted successively with dichloromethane (DCM) ( $\sim 900 \mathrm{~mL}$ for elderberries and $\sim 700 \mathrm{~mL}$ for elderflowers), followed by $96 \% \mathrm{EtOH}(\sim 950 \mathrm{~mL}$ for elderberries and $\sim 800 \mathrm{~mL}$ for elderflowers), $50 \% \mathrm{EtOH}$ ( $\sim 650 \mathrm{~mL}$ for elderberries and $\sim 500 \mathrm{~mL}$ for elderflowers), $50{ }^{\circ} \mathrm{C}$ water ( $\sim 50 \mathrm{~mL}$ for elderberries and $\sim 300 \mathrm{~mL}$ for elderflowers), and $100{ }^{\circ} \mathrm{C}$ water $(\sim 450 \mathrm{~mL}$ for elderberries and $\sim 300 \mathrm{~mL}$ for elderflowers). The anthocyanins from elderberries were isolated in accordance to Bräunlich et al. [41]. Briefly, freeze-dried elderberries were extracted by maceration with $\mathrm{MeOH}(0.5 \%$ trifluoroacetic acid (TFA) $v / v)$ for $24 \mathrm{~h}$. The dried extract was 
applied on an Amberlite XAD-7HP column $(5 \mathrm{~cm} \times 50 \mathrm{~cm})$ with water followed by $\mathrm{MeOH}(0.5 \%$ TFA $)$ as mobile phase. The anthocyanin-enriched fraction was then fractionated on a Sephadex LH-20 column $(5 \mathrm{~cm} \times 100 \mathrm{~cm})($ water-MeOH $(0.5 \%$ TFA) as gradient), and purified by preparative HPLC using a Microsorb 60-8 $\mathrm{C}_{18}(250 \mathrm{~mm} \times 21.4 \mathrm{~mm})$ column (Varian, Palo Alto, CA, USA) with a water-acetonitrile (0.5\% TFA) gradient as eluent.

\subsection{NMR Spectroscopy}

${ }^{1} \mathrm{H}$ and ${ }^{13} \mathrm{C}$ nuclear magnetic resonance (NMR) was conducted on a Bruker DPX 300 or a Bruker AVII 400 instrument (Bruker, Rheinstetten, Germany) with $\mathrm{CD}_{3} \mathrm{OD}, \mathrm{CD}_{3} \mathrm{OD}$ :TFA (95:5) or DMSO- $d_{6}$ as solvents and tetramethylsilane (TMS) as reference.

\subsection{Complement Fixating Assay}

The complement fixating test is based on inhibition of hemolysis of antibody-sensitized sheep red blood cells (SRBC) by human sera, as described by Michaelsen et al. [42] (Method A). Samples were dissolved in $0.1 \%$ DMSO or veronal buffered saline (VBS) pH 7.2 containing $0.2 \mathrm{mM} \mathrm{CaCl}_{2}$ and $0.8 \mathrm{mM} \mathrm{MgCl} 2$ with $2 \mathrm{mg} / \mathrm{mL}$ bovine serum albumin (BSA). A pectic polysaccharide, BPII, from Biophytum umbraculum Welw. (syn. B. petersianum Klotzsch) was used as a positive control [25]. A dose-response curve was constructed to calculate the concentration of the test sample that gave $50 \%$ inhibition $\left(\mathrm{IC}_{50}\right)$ of hemolysis. The experiments were repeated independently three times.

\subsection{RAW 264.7 and Dendritic D2SC/I Cells}

The mouse macrophages cell line RAW 264.7 and dendritic cell line D2SC/I were cultured in Dulbecco's modified eagle medium (DMEM) supplemented with $10 \%$ fetal bovine serum, $1 \% 100 \mathrm{mM}$ sodium pyruvate, $1 \%$ Pen Strep $(10,000 \mathrm{U} / \mathrm{mL}$ penicillin and $10,000 \mu \mathrm{g} / \mathrm{mL}$ streptomycin), and $5 \times 10^{-5} \mathrm{M}$ 2-mercaptoethanol and maintained in a $37^{\circ} \mathrm{C}$ humidified incubator containing $5 \% \mathrm{CO}_{2}$.

\subsection{Nitrite Assay}

The nitrite assay was carried out as previously described with minor modifications [28]. Macrophages and dendritic cells at a density of $5 \times 10^{5}$ cells $/ \mathrm{mL}$ were seeded into 96 -well flat-bottomed plates and pre-incubated with the test samples for one hour before the addition of $500 \mathrm{ng} / \mathrm{mL}$ LPS (Escherichia coli O55:B5, Sigma-Aldrich). Samples were dissolved in DMSO (0.1\% final concentration) or medium. The cells were incubated for $24 \mathrm{~h}$ in duplicates containing $0.1,1,10$, and $100 \mu \mathrm{g} / \mathrm{mL}$ (extracts) or $0.1,1,10$, and $100 \mu \mathrm{M}$ (pure compounds) of test samples (final concentrations). NO was determined by measuring the amount of nitrite, which can be measured in a colorimetric assay using the Griess reagents. The supernatant $(50 \mu \mathrm{L})$ was mixed with $50 \mu \mathrm{L}$ of Griess reagent A ( $1 \%$ sulfanilamide in $5 \%$ phosphoric acid) and incubated at room temperature in the dark for $10 \mathrm{~min}$. Then $50 \mu \mathrm{L}$ Griess reagent B (0.1\% N-(1-naphthyl) ethylenediamine dihydrochloride in water) was added, and the absorbance was measured at $540 \mathrm{~nm}$ using a Bio-Rad reader. Quercetin was used as a positive control. A serial dilution of $\mathrm{NaNO}_{2}$ in medium was used to construct the standard reference curve. Percentage NO inhibition was expressed as the percentage decrease in NO production as: $100-[\mathrm{NO}]^{\mathrm{a}} /[\mathrm{NO}]^{\mathrm{b}} \times 100$, where $[\mathrm{NO}]^{\mathrm{a}}$ represents the $\mathrm{NO}$ concentration for test samples and $[\mathrm{NO}]^{\mathrm{b}}$ represents the NO concentration from LPS-activated control. The experiments were repeated independently three times.

\subsection{Cell Viability Assay}

Cell viability was determined by the MTT assay. The assay is based on the cleavage of the yellow tetrazolium salt MTT to purple formazan crystals by metabolic active cells. The method was done according to the manufacturer's procedure [43]. Briefly, RAW 264.7 and dendritic D2SC/I cells were 
seeded into 96-well plates at a density of $5 \times 10^{5}$ cells/well and incubated with test samples $(0.1,1$, 10 , and $100 \mu \mathrm{g} / \mathrm{mL}$ (extracts) or $0.1,1,10$, and $100 \mu \mathrm{M}$ (pure compounds)) for $24 \mathrm{~h}$ in a humidified $6.5 \% \mathrm{CO}_{2}$ atmosphere at $37{ }^{\circ} \mathrm{C}$. After the incubation period, $10 \mu \mathrm{L}$ of MTT reagent was added to each well. After $4 \mathrm{~h}, 100 \mu \mathrm{L}$ of solubilization solution was added. The quantity of formazan (presumed to be directly proportional to the number of viable cells) is measured by recording changes in absorbance at $595 \mathrm{~nm}$ using a microplate spectrophotometer (iMark Microplate reader, Bio-Rad, 'Hercules, CA, USA). Medium was used as negative control and $20 \%$ DMSO as positive control. The experiments were repeated independently three times.

\subsection{Statistical Analysis}

Each assay was performed in duplicate or triplicate and results are given as mean $( \pm$ SEM) from three separate experiments. Comparisons of different treatments were evaluated by two-tailed Student's $t$-test. Statistical analyses were performed using GraphPad Prism 5.0 for Windows (GraphPad Software, San Diego, CA, USA).

Acknowledgments: The authors are grateful to cultivator Rune Hatleli for supplying elderberries and cold-pressed juice. The NMR laboratory at the Chemistry Department, University of Oslo, Norway is acknowledged for the spectrometer facilities. Oslo University Hospital is acknowledged for supplying RAW 264.7 macrophages and dendritic D2SC/I cells.

Author Contributions: Helle Wangensteen and Hilde Barsett conceived and designed the experiments; Giang Thanh Thi Ho performed the experiments, analyzed the data and wrote the paper. All authors read and approved the final manuscript.

Conflicts of Interest: The authors declare no conflict of interest.

$\begin{array}{ll}\text { Abbreviations } \\ \text { DCM } & \text { Dichloromethane } \\ \text { DMSO } & \text { Dimethylsulfoxide } \\ \text { EB } & \text { Elderberry } \\ \text { EF } & \text { Elderflower } \\ \text { EtOH } & \text { Ethanol } \\ \text { IC } & \text { Inhibitory concentration to give 50\% effect } \\ \text { LPS } & \text { Lipopolysaccharide } \\ \text { MeOH } & \text { Methanol } \\ \text { MTT } & \text { 3-(4,5-dimethylthiazol-2-yl)-2,5-diphenyltetrazolium bromide } \\ \text { NO } & \text { Nitric oxide } \\ \text { NMR } & \text { Nuclear magnetic resonance } \\ \text { TMS } & \text { Tetramethylsilane } \\ \text { TFA } & \text { Trifluoroacetic acid }\end{array}$

\section{References}

1. Bazzano, L.A.; He, J.; Ogden, L.G.; Loria, C.M.; Vupputuri, S.; Myers, L.; Whelton, P.K. Fruit and vegetable intake and risk of cardiovascular disease in US adults: The first national health and nutrition examination survey epidemiologic follow-up study. Am. J. Clin. Nutr. 2002, 76, 93-99. [PubMed]

2. Hämäläinen, M.; Nieminen, R.; Vuorela, P.; Heinonen, M.; Moilanen, E. Anti-inflammatory effects of flavonoids: Genistein, kaempferol, quercetin, and daidzein inhibit STAT-1 and NF-kB activations, whereas flavone, isorhamnetin, naringenin, and pelargonidin inhibit only NF- $\mathrm{kB}$ activation along with their inhibitory effect on iNOS expression and NO production in activated macrophages. Mediat. Inflamm. 2007. [CrossRef]

3. Gandini, S.; Merzenich, H.; Robertson, C.; Boyle, P. Meta-analysis of studies on breast cancer risk and diet: The role of fruit and vegetable consumption and the intake of associated micronutrients. Eur. J. Cancer 2000, 36, 636-646. [CrossRef]

4. Yoon, J.-H.; Baek, S.J. Molecular targets of dietary polyphenols with anti-inflammatory properties. Yonsei Med. J. 2005, 46, 585-596. [CrossRef] [PubMed] 
5. Dos Santos, M.D.; Almeida, M.C.; Lopes, N.P.; De Souza, G.E.P. Evaluation of the anti-inflammatory, analgesic and antipyretic activities of the natural polyphenol chlorogenic acid. Biol. Pharm. Bull. 2006, 29, 2236-2240. [CrossRef] [PubMed]

6. Tzianabos, A.O. Polysaccharide immunomodulators as therapeutic agents: Structural aspects and biologic function. Clin. Microbiol. Rev. 2000, 13, 523-533. [CrossRef] [PubMed]

7. Kolodziej, H.; Kiderlen, A.F. Antileishmanial activity and immune modulatory effects of tannins and related compounds on Leishmania parasitised RAW 264.7 cells. Phytochemistry 2005, 66, 2056-2071. [CrossRef] [PubMed]

8. Markiewski, M.M.; Lambris, J.D. The role of complement in inflammatory diseases from behind the scenes into the spotlight. Am. J. Pathol. 2007, 171, 715-727. [CrossRef] [PubMed]

9. Sarma, J.V.; Ward, P.A. The complement system. Cell Tissue Res. 2011, 343, 227-235. [CrossRef] [PubMed]

10. Lin, H.-Y.; Juan, S.-H.; Shen, S.-C.; Hsu, F.-L.; Chen, Y.-C. Inhibition of lipopolysaccharide-induced nitric oxide production by flavonoids in RAW 264.7 macrophages involves heme oxygenase-1. Biochem. Pharmacol. 2003, 66, 1821-1832. [CrossRef]

11. Wang, J.; Mazza, G. Inhibitory effects of anthocyanins and other phenolic compounds on nitric oxide production in LPS/IFN- $\gamma$-activated RAW 264.7 macrophages. J. Agric. Food Chem. 2002, 50, 850-857. [CrossRef] [PubMed]

12. Sidor, A.; Gramza-Michałowska, A. Advanced research on the antioxidant and health benefit of elderberry (Sambucus nigra) in food-A review. J. Funct. Foods 2014, 18B, 941-958. [CrossRef]

13. Mascolo, N.; Capasso, F.; Menghini, A.; Fasulo, M.P. Biological screening of Italian medicinal plants for anti-inflammatory activity. Phytother. Res. 1987, 1, 28-31. [CrossRef]

14. Heim, K.E.; Tagliaferro, A.R.; Bobilya, D.J. Flavonoid antioxidants: Chemistry, metabolism and structure-activity relationships. J. Nutr. Biochem. 2002, 13, 572-584. [CrossRef]

15. Ferrars, R.; Czank, C.; Zhang, Q.; Botting, N.; Kroon, P.; Cassidy, A.; Kay, C. The pharmacokinetics of anthocyanins and their metabolites in humans. Br. J. Pharmacol. 2014, 171, 3268-3282. [CrossRef] [PubMed]

16. Ferrars, R.M.; Cassidy, A.; Curtis, P.; Kay, C.D. Phenolic metabolites of anthocyanins following a dietary intervention study in post-menopausal women. Mol. Nutr. Food Res. 2014, 58, 490-502. [CrossRef] [PubMed]

17. Dubois, M.; Gilles, K.A.; Hamilton, J.K.; Rebers, P.; Smith, F. Colorimetric method for determination of sugars and related substances. Anal. Chem. 1956, 28, 350-356. [CrossRef]

18. Napolitano, J.G.; Lankin, D.C.; Chen, S.N.; Pauli, G.F. Complete ${ }^{1}$ H NMR spectral analysis of ten chemical markers of Ginkgo biloba. Magn. Reson. Chem. 2012, 50, 569-575. [CrossRef] [PubMed]

19. Dürüst, N.; Özden, S.; Umur, E.; Dürüst, Y.; Kucukislamoglu, M. The isolation of carboxylic acids from the flowers of Delphinium formosum. Turk. J. Chem. 2001, 25, 93-97.

20. Mikulic-Petkovsek, M.; Samoticha, J.; Eler, K.; Stampar, F.; Veberic, R. Traditional elderflower beverages: A rich source of phenolic compounds with high antioxidant activity. J. Agric. Food Chem. 2015, 63, 1477-1487. [CrossRef] [PubMed]

21. Andersen, Ø.M.; Aksnes, D.W.; Nerdal, W.; Johansen, O.P. Structure elucidation of cyanidin-3-sambubioside and assignments of the ${ }^{1} \mathrm{H}$ and ${ }^{13} \mathrm{C}$ NMR resonances through two-dimensional shift-correlated NMR techniques. Phytochem. Anal. 1991, 2, 175-183. [CrossRef]

22. Johansen, O.-P.; Andersen, Ø.M.; Nerdal, W.; Aksnes, D.W. Cyanidin 3-[6-(p-coumaroyl)-2-(xylosyl)glucoside]-5-glucoside and other anthocyanins from fruits of Sambucus canadensis. Phytochemistry 1991, 30, 4137-4141. [CrossRef]

23. Alban, S.; Classen, B.; Brunner, G.; Blaschek, W. Differentiation between the complement modulating effects of an arabinogalactan-protein from Echinacea purpurea and heparin. Planta Med. 2002, 68, 1118-1124. [CrossRef] [PubMed]

24. Grønhaug, T.E.; Kiyohara, H.; Sveaass, A.; Diallo, D.; Yamada, H.; Paulsen, B.S. $\beta$-D-(1 $\rightarrow 4)$-galactancontaining side chains in RG-I regions of pectic polysaccharides from Biophytum petersianum Klotzsch. contribute to expression of immunomodulating activity against intestinal Peyer's patch cells and macrophages. Phytochemistry 2011, 72, 2139-2147. [CrossRef] [PubMed]

25. Inngjerdingen, K.T.; Coulibaly, A.; Diallo, D.; Michaelsen, T.E.; Paulsen, B.S. A complement fixing polysaccharide from Biophytum petersianum Klotzsch, a medicinal plant from Mali, West Africa. Biomacromolecules 2006, 7, 48-53. [CrossRef] [PubMed] 
26. Ho, G.T.T.; Ahmed, A.; Zou, Y.-F.; Aslaksen, T.; Wangensteen, H.; Barsett, H. Structure-activity relationship of immunomodulating pectins from elderberries. Carbohydr. Polym. 2015, 125, 314-322. [CrossRef] [PubMed]

27. Shahat, A.A.; Hammouda, F.; Ismail, S.I.; Azzam, S.A.; De Bruyne, T.; Lasure, A.; van Poel, B.; Pieters, L.; Vlietinck, A.J. Anti-complementary activity of Crataegus sinaica. Planta Med. 1996, 62, 10-13. [CrossRef] [PubMed]

28. Ho, G.T.; Bräunlich, M.; Austarheim, I.; Wangensteen, H.; Malterud, K.E.; Slimestad, R.; Barsett, H. Immunomodulating activity of Aronia melanocarpa polyphenols. Int. J. Mol. Sci. 2014, 15, 11626-11636. [CrossRef] [PubMed]

29. Ho, G.T.T.; Zou, Y.-F.; Aslaksen, T.H.; Wangensteen, H.; Barsett, H. Structural characterization of bioactive pectic polysaccharides from elderflowers (Sambuci flos). Carbohydr. Polym. 2016, 135, 128-137. [CrossRef] [PubMed]

30. Ho, G.T.T.; Zou, Y.-F.; Wangensteen, H.; Barsett, H. RG-I regions from elderflower pectins substituted on GalA are strong immunomodulators. Int. J. Biol. Macromol. 2016, 92, 731-738. [CrossRef] [PubMed]

31. Qin, Y.; Wen, Q.; Cao, J.; Yin, C.; Chen, D.; Cheng, Z. Flavonol glycosides and other phenolic compounds from Viola tianshanica and their anti-complement activities. Pharm. Biol. 2015, 54, 1140-1147. [PubMed]

32. Min, B.-S.; Lee, S.-Y.; Kim, J.-H.; Lee, J.-K.; Kim, T.-J.; Kim, D.-H.; Kim, Y.-H.; Joung, H.; Lee, H.-K.; Nakamura, N. Anti-complement activity of constituents from the stem-bark of Juglans mandshurica. Biol. Pharm. Bull. 2003, 26, 1042-1044. [CrossRef] [PubMed]

33. Jung, K.Y.; Oh, S.R.; Park, S.-H.; Lee, I.S.; Ahn, K.S.; Lee, J.J.; Lee, H.-K. Anti-complement activity of tiliroside from the flower buds of Magnolia fargesii. Biol. Pharm. Bull. 1998, 21, 1077-1078. [CrossRef] [PubMed]

34. Fossiez, F.; Djossou, O.; Chomarat, P.; Flores-Romo, L.; Ait-Yahia, S.; Maat, C.; Pin, J.-J.; Garrone, P.; Garcia, E.; Saeland, S. T cell interleukin-17 induces stromal cells to produce proinflammatory and hematopoietic cytokines. J. Exp. Med. 1996, 183, 2593-2603. [CrossRef] [PubMed]

35. Bogdan, C. Nitric oxide and the immune response. Nat. Immunol. 2001, 2, 907-916. [CrossRef] [PubMed]

36. Da Cunha, F.M.; Duma, D.; Assreuy, J.; Buzzi, F.C.; Niero, R.; Campos, M.M.; Calixto, J.B. Caffeic acid derivatives: In vitro and in vivo anti-inflammatory properties. Free Radic. Res. 2004, 38, 1241-1253. [CrossRef] [PubMed]

37. Min, S.-W.; Ryu, S.-N.; Kim, D.-H. Anti-inflammatory effects of black rice, cyanidin-3-O- $\beta$-D-glycoside, and its metabolites, cyanidin and protocatechuic acid. Int. Immunopharmacol. 2010, 10, 959-966. [CrossRef] [PubMed]

38. Manach, C.; Williamson, G.; Morand, C.; Scalbert, A.; Rémésy, C. Bioavailability and bioefficacy of polyphenols in humans. I. Review of 97 bioavailability studies. Am. J. Clin. Nutr. 2005, 81, 230S-242S. [PubMed]

39. Williamson, G.; Manach, C. Bioavailability and bioefficacy of polyphenols in humans. II. Review of 93 intervention studies. Am. J. Clin. Nutr. 2005, 81, 243S-255S. [PubMed]

40. Ho, G.T.T.; Kase, E.T.; Wangensteen, H.; Barsett, H. Effect of phenolic compounds from elderflowers on glucose- and fatty acid uptake in human myotubes and HepG2-cells. Molecules 2017, 22, 90. [CrossRef] [PubMed]

41. Bräunlich, M.; Slimestad, R.; Wangensteen, H.; Brede, C.; Malterud, K.E.; Barsett, H. Extracts, anthocyanins and procyanidins from Aronia melanocarpa as radical scavengers and enzyme inhibitors. Nutrients 2013, 5, 663-678. [CrossRef] [PubMed]

42. Michaelsen, T.; Gilje, A.; Samuelsen, A.; Høgåsen, K.; Paulsen, B. Interaction between human complement and a pectin type polysaccharide fraction, PMII, from the leaves of Plantago major L. Scand. J. Immunol. 2000, 52, 483-490. [CrossRef] [PubMed]

43. Roche Cell Proliferation Kit I (MTT). Available online: https://www.sigmaaldrich.com/content/dam/ sigma-aldrich/docs/Roche/Bulletin/1/11465007001bul.pdf (accessed on 19 June 2016).

(C) 2017 by the authors. Licensee MDPI, Basel, Switzerland. This article is an open access article distributed under the terms and conditions of the Creative Commons Attribution (CC BY) license (http:/ / creativecommons.org/licenses/by/4.0/). 